\title{
UNDERSTANDING THE DOCTRINE OF THE TRINITY
}

\author{
Frederich Oscar L. Lontoh
}

Evangelical Theological Seminary of Indonesia-Surabaya

E-mail:oscarlontoh@sttii-surabaya.ac.id

\begin{abstract}
Many people have difficulty understanding the Trinity. Likewise, many Christians themselves do not understand this basic doctrine. Even more so for people outside of Christianity, they assume that Christians believe in three Gods or even think that God has a sexual relationship with Mary. There is also the opinion that the triune God is one person with three functions. The three views above are not true. Thophilus of Anthiokia was the first to use the term Trinity or trias in Greek. Whereas Tertullian was the first to use this term in Latin form. It was from Tertullian that the terms substance (substance) and person(personal, person) were used in formulating the concept of the Trinity. Every Christian must understand what is fundamental to his faith. The Trinity is a basic doctrine that must be correctly understood and accepted by every Christian. Without a proper understanding of this doctrine, it will undermine other related doctrines, namely the doctrine of creation, the doctrine of Christology, the doctrine of redemption, and the doctrine of eternal life. The trinity doctrine is a doctrine which is accepted by all Christian churches for almost 2000 years. Only heretical schools and deviant movements do not accept this doctrine.
\end{abstract}

Keywords: Doctrine, Trinity, God is one, Christianity

\section{INTRODUCTION}

The doctrine of the trinity is not a concept created by church fathers or theologians of the 3rd century AD. But the trinity doctrine is a concept that is purely derived from the Bible which is the word of God and appears implicitly and explicitly in the Bible. There may be difficulties in understanding this, but however difficult it is to understand the trinity because we are human beings who are trying to understand the nature of God. Humans are creatures and God trinity is creators. In this case the creation is trying to understand its creator. So it is not uncommon for a creature to find it difficult to understand what is in the nature of its creator.

The doctrine of the Trinity is a doctrine that goes beyond the ratio of humans (suprarational) which is why it is difficult to find analogies that can describe this doctrine. But this does not mean contrary to ratio (counterrational). Counter rational means illogical, contrary to the way of thinking and all the principles for bringing thing that needs to be stressed here is that

humans as creatures from God and are trying to understand their creator are ONLY based what is in His words in the Bible. What is not in the Bible, either explicit or implied cannot be used as a basis for knowing God. So we are not investigating a perception but we are investigating and digging into something that is already in the biblical scriptures that is believed to be the word of God. There is no other place that is authoritative, authentic, better, truer, more precise and more legitimate that God has provided for us humans to study the nature of Himself than the Bible itself. When the Bible says something, we must accept it on the basis of faith. Because the Bible is the word of God. God cannot be wrong and therefore His words in the Bible also cannot 
be wrong. If we find a difference between the Bible and our understanding or human logic, we must accept the Bible as truth because the Bible is God's statement. We believe that human logic cannot solve problems or explain perfectly the statements of Allah Almighty.

Definition of God Definition is a boundary or meaning, it can also be interpreted words, phrases, or sentences that express the meaning, description, or the main characteristics of people, objects, processes, or activities. To know God humans need to make definitions. Making a complete definition to describe God is an impossibility. But that does not mean that humans cannot make a definition of God to the extent that humans and their languages know God.

According to Buswell, "The best summary of the doctrine about God taught by the Bible is found in the answer to question number four in Wesminster Shorter Catechism, 'What is God? God is spirit, unlimited, eternal, unchanging in Himself, His mercy and His truth. Hoeksema states," God is one, undivided and absolute, spiritual person solely, possessing infinite perfection in His knowledge and wisdom of His goodness and love, His grace and mercy, truth and holiness - Him. "4 While Berkof defines God as follows," God is one, perfect, unchanging, and unlimited in His knowledge and wisdom, His truth and holiness. Furthermore according to Strong," God is an infinite Spirit. and perfect; in Him all things are sourced, preserved, and ended. So if we summarize some of God's definitions above, it can be said that God is something that is very powerful, which is almighty because so great is His power that humans cannot think of it. This is the basis why humans cannot understand God completely and comprehensively. Because if you can then God is limited. If we know and believe that God is a Spirit that is not limited by time and space, then it is possible to state that God is one in the sense of simple unity that is also impossible. If we insist to declare God to be one in the sense of simple unity, then actually we are limiting God and belittling Him because simple unity cannot be used to interpret the Spirit of God which is unlimited in space and time. This is the same as when we interpret water and air.
Can we state that water and air are one in the sense of simple unity. While in this world there is no place that cannot be attended by water and air. Every inch of the world has air there (except for man-made vacuum) and water (except man-made waterproof spaces). That's just water and air that is still limited by time and space. Especially when we talk and think about the SPIRIT OF GOD, which is not limited by time and space. How to study God? A knowledge of God is knowledge based on facts and also personal. Knowing the facts about someone without knowing them personally is limited; conversely knowing someone personally without the facts is superficial.7 Therefore, humans need to know God personally and also in fact.

\section{GOD CANNOT BE COMPARED AND CANNOT BE FULLY UNDERSTOOD}

To begin this discussion, we must understand one important thing, that God is incomparable to anything and anyone and cannot be fully understood by His entire nature. According to the Bible:

1. Isa 46: 9 "... I am God and there is no one like me, ..." 2. Exo 9:14 "... that there is none like me in all the earth." 3. 2 Sam 7:22 "... for there is no one like You and there is no God but You ..." 4. Ps. 145: 3 "... and His greatness is unexpected." 5. Isa 46: 5 "To whom? you want to make me equal, to compare and compare me, so that we are the same? "6. Isa 40:18" So who do you want to be with God, and what can you think is similar to him? " The Qur'an also claims the same thing, 1. Q 42:11 "There is nothing like Him, and He is the One who hears and sees." 2. Q 112: 4 "... and there is no one who is equal to Him." God not only has no resemblance or similarity to anything but God is also greater than anything. Job 11: 79 "Can you understand the nature of God, delving into the limits of Almighty power? As high as the sky can you do? In it beyond the world of the dead what can you know? Longer than the earth its size, and wider than the ocean. " Q 2: 255" Allah knows what is before them and behind them, and they do not know anything from the knowledge of Allah but what He wants ." 
Q 6: 103" He cannot be reached by eye sight, while He can see everything that is seen; and $\mathrm{He}$ is the Most refined, the Allknowing. " With God's unlimited self-identity, we should not be surprised and surprised that we must move on from the normal human categorical thinking in understanding the trinity.

\section{LIMITED HUMAN MIND.}

One of the problems humans understand God is that humans are limited and limited by human language and thought when we talk about something as infinite and noble as God. So how can we talk about God? Ryrie explained, "Knowledge of God will be different from all other knowledge. In the knowledge of God, humans can only get it as far as God reveals it. If God does not take the initiative to reveal Himself, it is impossible for humans to get to know Him. Therefore humans must place themselves under God who is the object of knowledge. In other scientific endeavors, humans often place themselves above the object of their investigation, but this is not the case in studying God. "8 In other words that humans cannot find their own understanding of God without God revealing himself to humans. Both the Holy Book and the Qur'an state that God revealed the following: Q 42:51 "And it is not possible for a human being that Allah speaks with him except by means of revelation or behind the veil or by sending a messenger (angel) and then revealed with His permission what He wants. Surely He is Most High and Most Wise. Deuteronomy 29:29" The hidden things are to the Lord our God, but the things which are not revealed are for us and for our children forever, so that we do all these words of the law. "In other words, the concept of our understanding of God and even throughout human history has never included God in the limitation of human thought and language. So humans can only receive information about God with all its limitations through revelation from Him who has been recorded in the scriptures, that outside the scriptures information about God can not be believed to be true.

\section{LANGUAGE AND HUMANS}

There is a close relationship between human language and human intellectuals and the insights they master. Language becomes important when God wants to express himself above human capabilities and insight. For this purpose God gave humans language. He gave the language to humans so that He could convey his commands to His creation (Gen. 1: 28-30). Language also distinguishes humans from animals. No matter how smart the Monkey, he was never together with other monkeys to plant bananas and build houses. Language shows systematic and orderly thinking activities.

A philosopher from Vienna Austria, Ludwig Wittgenstein stated that "The limits of my language are the limits of my world." So that the limitation of human language in understanding the nature of God is what makes humans unable to fully understand nature God'sas a whole.

Karl Barth in hisopus magnum theology Church Dogmatics, he wrote: "The images in which we look at God, the thoughts in which we think of Him, the words with which we define Him, are actually not all worthy of the object this and therefore it is not appropriate to express and affirm knowledge of Him. nature of God that humans cannot fully comprehend shows that $\mathrm{He}$ is a God without His omnipotence. If humans can understand Him completely and correctly then it is questionable to His Greatness. To understand planet Earth and everything in it that we meet and live in every day is not easy. Humans need a long time to manage and understand nature on this planet so that they get progress as it is today. Likewise, studying God. It is impossible for humans to understand Allah Almighty with this limited human brain. Humans are simple and small creatures in the presence of Almighty God who is trying to understand His creator. This natural man is trying to understand the Supernatural God. That is, God is very understanding to our limits to understand what $\mathrm{He}$ is like. That is why God only wants humans to understand $\mathrm{Him}$ as what $\mathrm{He}$ has revealed about natureHisto humans, namely through His words recorded in the Scriptures. The Bible records and reports what was revealed. 


\section{ROLE OF GOD'S SPIRIT TO GIVE UNDERSTANDING.}

In understanding the super-natural, infinite and uncontrolled God of limited human thought, we need a credo or belief in his words or a belief in what he has revealed to humans. Only then can humans understand God correctly.

God gives His Spirit to those who want to understand Him properly. He gave His Holy Spirit to the believers to declare matters which originated from Him. The Spirit of God will open our limited minds to be able to understand God's unlimitedness. Humans are often just to study Him as an object.

Anselm from Canterbury once said in Latin "credo ut intelligam" which in English can be translated as "I believe so that I may understand" which means that I must believe / believe first and then I can understand. The phrase comes from Agustnus's expression from Hippo, " believe so that you may understand" or "crede ut intelligas." God is ESA Statement of the Holy Bible and the Qur'an. Deuteronomy 6: 4 "Hear, O Israel: God is our God, God is one!" Mark 12:29 "Jesus answered:" The main law is: Listen, O Israel, Lord our God, God is one. " Romans 3:30 "That is, if there is one God, who will justify both the circumcised by faith, and the uncircumcised also by faith." 1 Cor 8: 6 "... but for us there is only one God alone, namely the Father, from whom all things come and for whom we live, and one God alone, namely Jesus Christ, by whom all things were made and through

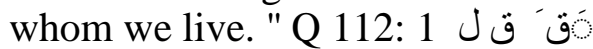

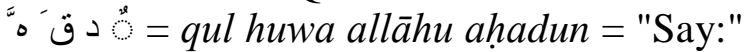
He is Allah, the One. " Ahadun = is a noun (Masculine, Nominative, Singular, Indefinite).

Root: اهح ('ḥ) Lemma: "هl (ahad)

From the verses above it can be concluded that God is only one and not many

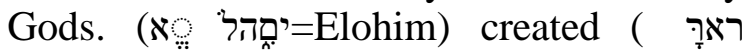
$\square=$ bara) heaven and earth. The word Allah used there in Hebrew uses the word Elohim, anoun plural, but the word 'coined' using the word 'ember' is aform of action single. In this case we find the plural and singular forms of divinity displayed clearly and decisively from the start. So there is plurality (plurality) in the unity of God.
Theterm Elohim pluralis usually used by writers in the Old Testament using a single verb and adjective to indicate a single idea Gen

1:26. Allah said: "Let us ( na'aseh= ע שד̣, $=$ Let Us make) make man in our image and likeness

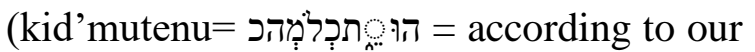

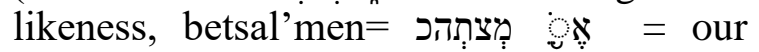
image), that they might rule over fish in the sea and birds in the air and over cattle and over all the earth and all animals. " Ge 3:22 The Lord God said,"

Behold, man has become like one satu (s९ व९ = ke'akhad = like one )from us (כיכ) = mimenu= of us) knowing about good and evil; so now In the Bible there are two words in Hebrew that mean 'one'. The first word is yachid which shows the meaning of units mathematically, which is a unit simple(simple unity). The second word is echad. The word echad shows a(complex unitycomplex unity), a combination of different elements into an entity. When Adam and Eve were united in marriage, it was said that they became one (echad) / united.

Gen 2:24. For this reason a man will leave his father and mother and unite (क्र $P$ =vedavag=and be joined) with his wife, so that the two become one ( $\left.\kappa_{n}\right\urcorner=$ echad=one) flesh. Many people / individuals living around the city and the tower of Babel are mentioned in Gen. 11: 6 ... 'one nation' / 'one (echad) people' / 'the people is one' (KJV). Gen 11: 6 "... and He said: They are one nation with one language for all ..." The prophet Ezekiel (Ezek 37:17) was instructed to combine two pieces of wood in his hands so that they became one (echad). This is a sign that God wants to bring the two kingdoms of Israel together as one.

Eze 37:17 "Combine the two into one (echad) board, so that they become one in your hand."The same word is used in Deuteronomy 6: 4 "... The Lord is our God, the Lord is one!

(echad).

This shows that God is a complex entity, not a simple unit like a number in mathematics. However, according to Ryrie, "Inferring the personal equality of his own name is doubtful. However, when God speaks about Himself with plural pronouns (Ge 1:26; 
$3: 22 ; 11: 7$; Isa $6: 8)$ and plural verbs (Gen $1: 26 ; 11: 7)$ it seems to indicate that there are different Persons, although it only shows that there is not special trinity. Furthermore, according to Ryrie, there are several Scriptures that explain the different Persons in the Godhead, namely:" 1) God is distinguished from God (Gen. 19:24; Hos 1: 7 ), 2) The redeemer (who must be divine) is distinguished from God (Isa 59:20), the Spirit is distinguished from God (Isa 48:16; 59:21; 63: 9-10). In these verses the Spirit is Personal and active.

God the Father, God the Son and God the Holy Spirit The Bible has more than 240 names and titles for God. Statistically, the word God in the Bible can be divided as follows. The word God refers to 'Father' is mentioned: 25 times in the OT 228 times in the NT. The word Allah refers to 'Son' is mentioned: 120 times in the NT. The word God refers to the Holy Spirit is mentioned: 92 times in the OT 301 times in the NT.

\section{IS JESUS GOD? PRE-INCARNATION IN THE OT}

Micah 5: 1 "But you, O Bethlehem Efrathah, the smallest of the families of Judah, from you shall rise up for me a man who will rule Israel, whose beginning is from time immemorial, long ago . " Isa 9: 6" For a child has been born for us, a son has been given to us, the government is over his shoulder, and his name is mentioned: Magic Counselor, Mighty God, Eternal Father, King of Peace. "

Counselor Magical (Wonderful = (Wonderful $=$ peleh $=$ a $\boldsymbol{R}_{\mathrm{Q}} \mathrm{h}$, Conselor $=$ Yoetz = wi ). "Counselor" of the word "Yoetz" which means someone who has the wisdom and divine ability to judge and observe through events that exist so as to see God's will and its application. While the word "Magic /Wonder" from the word "Peleh" which means a big secret. So as a Magic Counselor he is able to see and penetrate a great secret of God that He will do according to God's will. Allah the Mighty

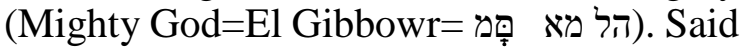
$\mathrm{El}$ comes from the Elohim and indicates the nature of his person (the divine qualities of his) and is always used as the name of God the Eternal Father (Everlasting

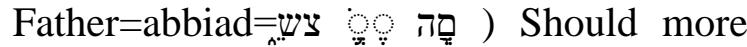
accurately said Father, owner of eternity. But what is being discussed here is the coming Messiah, the second Person of the Triune God. He mastered the age. From Him time comes true. King of Peace (Prince of

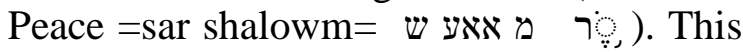
term uses "Sarshalom". This term is also used in Zechariah 9:10; Eph 2:14; Col. 1:20. This states that the coming Messiah is the Prince of Peace.

\section{NT STATEMENT ON THE DIVINITY OF JESUS MATT. $1: 23$}

John 1: 1-3 "In the beginning was the Word; The Word is with God and the Word is God. He was all together with God. Everything was made by him and without him nothing has been made.

According to Dr. Chris Marantika in his book "Christology" states, "The words" in the beginning "were translated from the Greek words"en"which.

means"in"or"in"and"arche"which means"ancient ", (without articles), then this means that the archeology is unlimited (timeless existence).

Coupled with the use of the form of "imperfect", namely the description of the time "past continuous" for the word "is" (en), then it is clear what is meant here is the past is not limited (timeless existence) or immortality of the past. The word "together with" comes from the word "pros" (face to face) which in Greek mind means unity, showing that Christ who is the Word not only exists continuously in the past that is infinite (eternal), but also states His union with God.

The theological meaning of the whole revelation of God is that the Word which is Christ is eternal, because $\mathrm{He}$ is God Himself. John 3: 13,16,17 (13) No one has ascended into heaven, other than the One who has descended from heaven, namely the Son of Man. (16) Because God so loved the world that He gave His only begotten Son, so that everyone who believes in Him will not 
perish, but have eternal life. In these two verses it is stressed that who Jesus was and before $\mathrm{He}$ was present in this world. That $\mathrm{He}$ is in Heaven together with Father, in other words Jesus already exists in the eternity of the past. Only God can exist in the past. Verse 13 further confirms that He is not just a prophet and apostle as he had been before. Only those who come from there (Heaven) who are together with the Father and Equals with the Father and so know well the contents of the heart and will of the Father can make such statements. Jesus even claimed and declared power as the path appointed by the Father as a Mediator with humanity. He wants everyone to believe in Him.

Phil 2: (9) "That is why God so exalted him and gave him the name above all names, (10) so that in the name of Jesus every knee is bowing in the heavens and on the earth and under the earth, and every tongue confesses: "Jesus Christ is Lord," to the glory of God, Father!

Joh 5:18 "... but also because He said that God is His own Father and thus identified Himself with God.

Joh 10:33 The Jews answered, "It is not because of a good work that we are willing to stone you, but because you blaspheme God and because you, even if only a human being, likens yourself to God.

1. Tim 3:16 And verily the great secrets of our worship: "He, who has revealed Himself in human form, is justified in the Spirit; who appeared to angels, preached among the nations that did not know God; who is trusted in the world, lifted up in glory.

2. Cor 13:13 "the love of the Lord Jesus Christ and the love of God and the fellowship of the Holy Spirit, be with you all."

1 Pet 1: 2 "... those chosen, according to the plan of God, our Father, and those who sanctified by the Spirit, to be obedient to Jesus Christ and receive His splash of blood.
May grace and peace abound even more upon you.

\section{JESUS 'OWN STATEMENT}

John 8: 56-59" I say to you, truly before Abraham became, I have existed. "In this verse Jesus' uniqueness is unconstrained by time and space. According to Chris

Marantika, the phrase "I say to you" is a way of teaching with power, certainty and firmness. "Real" conversation emphasizes the truth of His statement. The word "before" refers to a certain period, namely the preexistence of Abraham. The word "so" is a verb with antime description aorist which describes something that happened definitely at some time in the past. This refers to the existence of Abraham. What attracts attention is the expression "I exist" (less accurately the phrase is translated I have existed). Jesus uses the description of the present time here, which means a habit is always there. So here Jesus Christ with full power of firmness and certainty based on Histruths, emphasizes that $\mathrm{He}$ is more than the father of Abraham, because $\mathrm{He}$ was there, now exists, has always been, and has never been, He is eternal. The only eternal person is the Lord God. So Jesus is God. Joh 10:30 "I and the Father are one."

Joh 10: (37) "If I do not do the works of My Father, do not believe in Me, (38) but if I do and you will not believe in - Me, believe in those works, so that you may know and understand that the Father is in me and I am in the Father. "Joh 13:13" You call me Teacher and Lord, and you say that is right, forindeed the I amTeacher and Lord. "Joh 17: 5 Therefore, O Father, glorify Me on your own with the glory that I have in Your presence before the world came into existence. According to Chris Marantika, "... this phrase begins with the same request as His request in verse 3 . Three reasons for prayer like this: (1)

Consolation for his students who are disappointed because they are demeaned. (2) Teaching us that suffering for God is the way to glory. (3) The development of the church depends on the glory of Christ (the designation of the church). As mediator $\mathrm{He}$ pleads for return to His original glory. 


\section{IS THE HOLY SPIRIT GOD?}

The Bible states the deity of the Holy Spirit as follows: Matt 28:19 Therefore go and make disciples of all nations and baptize them in the name of the Father and of the Son and of the Holy Spirit, Luke 12:10 Everyone who says anything against the Son of Man, he will be forgiven; but whoever blasphemes the Holy Spirit, he will not be forgiven. 2 Cor 13:14 The grace of the Lord Jesus Christ, and the love of God, and the fellowship of the Holy Ghost be with you all. Eph 4: 4-6 one body, and one Spirit, as you have been called to the hope contained in your calling. The use of the nouns of the Holy Spirit and God is the same. Acts 5: 3-4 But Peter said: "Ananias, why is your heart controlled by Satan? so that you deceive the Holy Spirit and withhold a portion of the proceeds of the sale of the land? As long as the land is not sold, does not it still belong to you, and after being sold, does the result remain in your power? Why do you plan the deeds in your heart? but lying to God Relationship and differentiation of the three personal roles of God. There are three parts in the OT, we find the third the person of God is explained together.In the first two parts, the Messiah, Jesus Christ speaking from himself with God the Father and God the Holy Spirit, Jesus describes himself as has been sent to carry out God's mission in the world. In the NT Jesus refers to himself as being 'sent' 43 times. Namely: - Joh 4:34, 5: 23-24, 30, 36-37; 6:29,

$38-39,44,57 ; 7: 16,28-29,38-39,44,57$; 7:16, 28-29; 8: 16,18,26,29,42; 9: 4; 10: 36; 11: 42; 12: 44-45; 49: 13-20; 14:24; 15:21; 16: 5; 17: 3,8,18,21,23,25; 20: 21. - Matt 10:40; 15:24; - Luke 4:43. The OT revealed the origin of this 'sending' theme. Yes 48:16 ' The OT revealed the origin of this 'sending' theme. Isaiah 48:16 'Come near unto me, hear ye this: I have not spoken in secret, and in that day that I was there.' And now, the Lord God has sent me by his Spirit. Messiah describes himself as the agent of creation. He refers to himself as the 'first and last' which is the nature of God. Isaiah 44: 6 "Thus saith the LORD, the King of Israel, and the Redeemer of the LORD of hosts ;" I am the first, and I am the last; there is no other God but me.
This is applied to Jesus and repeated twice in PB. Revelation 1: 17-18 “... Do not be afraid! I am the Beginning and the End, and the Living. I am dead, but look, I am alive, and I hold the keys of death and of the kingdom of death. Revelation 22:13 "I am the Alpha and the Omega, the First and the Last, the Beginning and the End." He was sent by God the Father and was working with the Spirit of God. In the second part, the theme of Messiah filled with the Spirit of God continues as it is referred to as the messenger sent by God the Father. Isaiah 61: 1-2 "The Spirit of the Lord is upon me, because the Lord has anointed me.

He has sent me to preach good news to the poor, and to take care of the brokenhearted, to proclaim liberty to the captives, and to the captives from prison, to proclaim the year of the Lord's mercy and of the day. the liberation of our God, to comfort all who mourn. Jesus explicitly applied this section to himself as he spoke in the synagogue in Nazareth. Luke 4:21 ". This day must be fulfilled when you hear it." These verses also refer to the 'power of the Spirit', empowering Jesus to do the work $\mathrm{He}$ received from God the Father and fulfill the prophecy.

In the third section, the reference is to the angel of God or messenger. The Hebrew word angel can be translated in two meanings. It is explained as being sent by God the Father and in NT Jesus is the savior of mankind. Luke 2:11 "Today the Savior, Christ the Lord, was born to you in the city of David. John

$4: 42$ “... they say unto her, We believe, but not according to thy word:

for we have heard him ourselves, and we know

that he is the Savior of the world." Isaiah 63: 8- 10 "It is not he who says," Surely they are my people, children who will not deal treacherously, "and he will be their Savior in all their troubles. Not an ambassador or envoy, but He himself saved them; He is the one who redeems them in His love and mercy. He lifted them up and carried them all the time long ago. But they rebelled and provoked His Holy Spirit; then he turned them into their enemies, and he himself fought against them. 
The Angel of Yahweh, according to Ryrie, "is sometimes referred to as God, but is different from Him (Gen. 16: 7-13; 18: 121; 19: 1-28; Mal 3: 1). This shows that there is a personal difference in God. Because the angel is called God, it is impossible for him to be just a prophet, who worked in the preprophetic times.

\section{CONSISTENCY OF THE TRINITY CONCEPT IN NT}

More than 60 sections of the NT provide descriptions or explanations of the concept of God the Father, God the Son Jesus Christ and the Holy Spirit at the same time. The passages are: 1. Matthew 3: 1619, 10: 18-20, 12:28, 22: 43-44, 28: 19-20, 2. Mark 1: 9-11, 12:36, 3. Luke 1: 30-35, 3: 21-22, 11: 9-12, 4. John 4: 24-25, 14: 16-17, 14: 26-27, 15:26, 16: 13- 15,

20: 21-22, 5. mortgage 1: 7-8, 2: 32-33, 2 : 3839, 5: 31-32 6. Romans 1: 1-4, 5: 5-6, 8 : 1617, 14: 17-18, 15: 15-16, 15:30, 7. 1 Cor 2: 1016, 12: 4-6, 8. 2 Cor 1: 21-22, 3: 3 , 3: 4-6, 13:14, 9. Galatians 3: 11-14, 4: 6, 10. Ephesians 2:18, 3: 14-17 11. Col 1: 6-8, 12. Hebrews $9: 14,13.1$ Peter 4:14, 14. 1 Jn 3: 21-24, 4: 2-3, 4: 13-14, 5: 1-6, 5: 8, 15. Jude 20:21 Revelation 1: 4-6, 2: 27-29, 3: 1-2, 3: 56, 3: 11-13, 3: 21-22, 5: 6-7, 14: 12-13 Bible proclaimed God as the Trinity, a complex unity of the three persons of the Father, Son and Holy Spirit. How can God be one and three personal at the same time? It is important to understand the difference betweensimple unityandcomplex unity.

The concept of Three in One Christians understand the concept of the unity of God and His three-person or Trinity revelation. God is defined as three different persons but one essence (one divine essence). How can something or someone say one but three at the same time. There are manyexamples three in onein our everyday world. For example in time. Time comes in three forms: past, present, andfuture, but has the same element of time. Place (space)consists of three dimensions: length, width and height. The material (matter)have three forms: solid, search and gas. Water (H2O) can be present in three forms namely solid ice, water vapor, and water at the same time. Atom has long been believed to be the smallest part but it is also known as Proton, Neutron and Electron. Some people reject the concept of trinity with a simple mathematical model of $1+1+1=1$ or $\infty+$ $\infty+\infty=\infty$, in many cases God is personal and not just a simple mathematical equation. All physical analogies have weaknesses. But these examples is to help us understand that an entity can be a three-in-one(threein one) at the same time. Trinity as a complex concept of unity We can actively see the trinity at the time of Jesus' baptism. When Jesus came out of the water, the Holy Ghost descended in the form of a dove and God the Father spoke from heaven: Mat 3:17 "This is my beloved Son, in whom I am well pleased.

Then Jesus told his disciples to be baptized in the name (single) of God the Father and of the Son and of the Holy Spirit '(Mat 28:19). The Trinity expresses one fundamental essence of the Godhead which is divided into three personalities of the Father, Son and Holy Spirit. When Jesus says in John 10:30 'I and my Father are one', he uses the term hen in Greek which means neutral, not the term masculine (heis).

One in this is not a single person (masculine), but one essence(neuter). God the Father, the Son and the Holy Spirit are three persons, but each person is God. The tables of God the Father, the Son, and the Holy Spirit each reveal his actions / attributes and attributes as God.

\begin{tabular}{|c|c|c|c|}
\hline $\begin{array}{c}\text { The Deeds } \\
\text { and } \\
\text { Attributes } \\
\text { of God the }\end{array}$ & Father & Son & Holy Spirit \\
\hline Permanent & $\begin{array}{c}\text { Romans } \\
16: 26-27\end{array}$ & $\begin{array}{c}\text { Romans } \\
1: 17\end{array}$ & $\begin{array}{c}\text { Hebrews } \\
9: 14\end{array}$ \\
\hline Creator & $\begin{array}{c}\text { Pslam } \\
100: 3\end{array}$ & $\begin{array}{c}3 \text { Col } \\
1: 16\end{array}$ & $\begin{array}{c}\text { Psalm } \\
104: 30\end{array}$ \\
\hline Omnipresent & Yer & Eph & Pslam 139: \\
& $23: 24$ & $1: 23$ & 7 \\
\hline Know & $\begin{array}{c}1 \text { John } \\
\text { Joh }\end{array}$ & $\begin{array}{c}1 \text { Cor } 2: 10 \\
1: 23\end{array}$ & \\
\hline Almighty & Eph 1:15 & Mat $8: 31$ & 1 Cor $12: 10$ \\
\hline Giving & Genesis & John & Romans $8:$ \\
Life & $1: 11-31$ & $1: 4 ; 5: 21$ & $10-11$ \\
& & \multicolumn{2}{|c}{} \\
\hline
\end{tabular}




\begin{tabular}{|c|l|l|l|}
\hline Strengthens & $\begin{array}{c}\text { Pslam } \\
138: 9\end{array}$ & Phil 4:13 & Eph 3:16 \\
& & & \\
\hline Light & $\begin{array}{l}\text { James } \\
1: 17\end{array}$ & $\begin{array}{l}\text { John } \\
8: 12\end{array}$ & 2 Cor 4: 6 \\
\hline Love & John & John & Romans 5: 5 \\
& $16: 27$ & $14: 21$ & \\
\hline
\end{tabular}

In the trinity is also explained that there are three different personalities in one Godfact. Each person is God but the three personalities are different from each other. Like the symbol below.

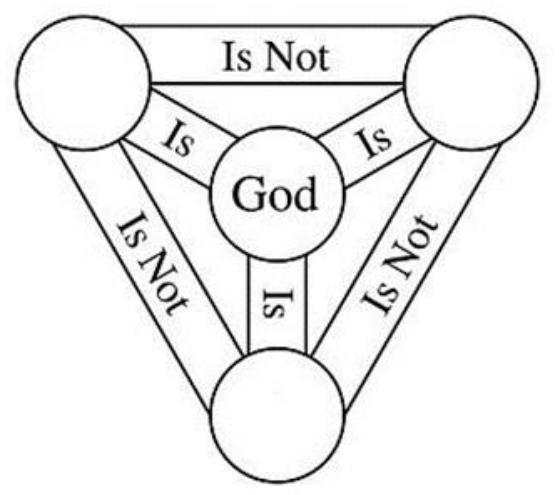

Why Trinity is so important Trinity helps us understand. God Who He Is and How It Works. - God is about relationships and always will be. The Bible says that God is love (1 Jn. 4: 8). But love always needs an object or person to love. Before man was created, love existed between the three personalities of the trinity. Jesus said to the Father; 'Thou lovedst me before the foundation of the world' (John 17:24) - God is a Spirit and is not limited to

space and time. If God is a union of simple(simpleunity)limited space and time, how God could come and live in the world (take the appearance as a man, Jesus) and if you can not do that, then he can not continue his work to set all over the world. God is limited. The Trinity's understanding is more flexible.

God saves us by entering the world through the teamwork and cooperation of God personally. The three personalities take on different tasks and roles and God finds us in each of His ways. God the Father is our God. It is a source of safety and security. He made our salvation possible by sending His Son (Jn 4:34). Jesus is God with us (Emmanuel). Jesus is the Word of God, the meaning and expression of salvation. He became a man (Jn. 1:14) and was nourished by the Holy Spirit (Luk 4:18).

Jesus the Son of God entered our world so that He could die for our sins and for the sins of the whole world. He shed His blood for this world. (Luke 22:20). The Holy Spirit is God in us. The Holy Ghost is an agent and a part of salvation. It works out salvation, giving us new life and transforming us from the inside out (2 Cor 3:18). Only God in the Holy Trinity can appear with flexibility and love.

\section{GOD'S STATEMENT IN THE QUR'AN}

In the Quran God speaks of himself in singular and plural form. In verse 2: 30-40, the Lord speaks of him as follows: Q2:34 ق لمل وا حق او قءحامل حواق او ق... wa- IDH qulnā lil- malā'ikati isjudū li- Adam fa- Jadu Illa $=$ '... remember when we spoke to ...' Qulna $=$ Perfect Verb (Plural, 1P, Form I, Root: J

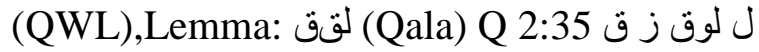
امو ق له ل امحق ق ق ق نل ووك و لwa- qulnā yāAdam Maskun wa anta- zawjuka 1Jannat'And We said ...' wa-qulnā = قand we said. Coordinating conjunction (wa), Perfect Verb (Plural, 1P, Form I, Root: لو (QWL),

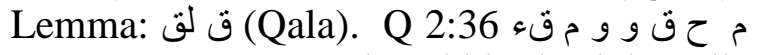
wa- qulnā ahbiṭū ba'ḍukum liba'da'aduwwun wa- lakum = '... from the state of things and We say ...' wa-qulnā and we said = Resumption Particle (wa), Perfect

Verb, Plural, 1P, Form I, Root : ل

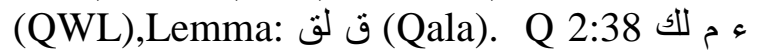
طض او ق ن للك ق ع كو ق كم م للك Minh jāmi' fa- ya'tiyannakum Emma Minna 'We said ... if it comes my instructions. ق ق للك و ق زل دب ق ف او ق ض ص ق ف wa- lladhīna kafara waKadhdhabū bi- Yatina Ūlā'ika Ashabu'... denySigns Our.. . 'bi-Yatina $=$ with Our Signs $=$ ParticlePreposition, Noun (Feminine, Genitive, Plural, Root: اي (yY), Lemma: $\forall$ (verse) The second word is echad which etymologically related to the word Sunday in Arabic language. Q 112: 1 
"Say:" He is God, the One (Sunday). " In the Qur'an in Q 2:87 it states" ... We (Allah) give the proof of the truth to Jesus the Son of Mary and We strengthen it with the Holy Spirit Qudus ... "Q 2: 253" ... and We (God) gave Jesus the Son of Mary some miracles and strengthened him with the Holy Spirit ... " Q 4:171

$$
\text { قَلَ }
$$

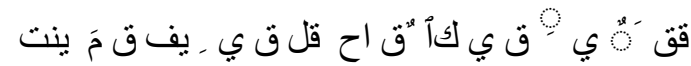

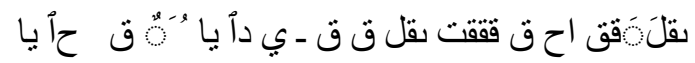

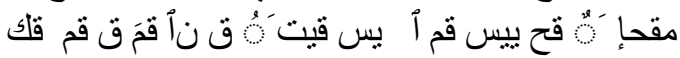

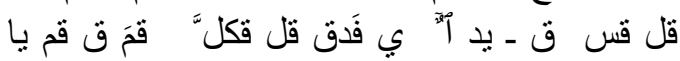

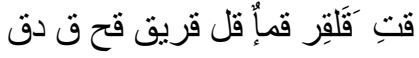

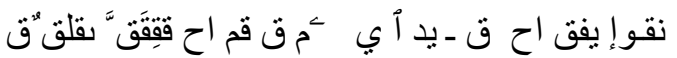$$
\text { اح قل ق قل قلك قليق يد }
$$

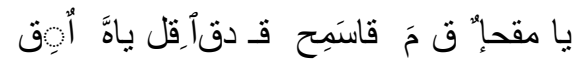

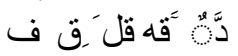

$$
\begin{aligned}
& \text { قاقي }
\end{aligned}
$$

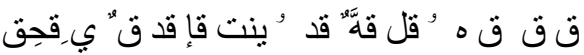

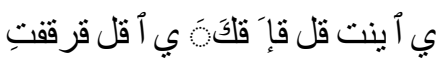

$$
\begin{aligned}
& \text { ق - يد آ قل برستي ي }
\end{aligned}
$$

yā'ahla 1-kitābi lā taghlū fĩ dīnikum wa-lā taqūlū 'alā allāhi illā l-ḥaqqa innamā l-masīhu 'īsā ibnu maryama rasūlu allāhi wa-kalimatuhu alqahā ilā maryama wa-rūḥun minhu fa-āminū billāhi wa-rusulihi wa-lā taqūlū thalāthatun antahū khayran lakum innamā allāhu ilāhun wāḥidun subḥānahu an yakūna lahu waladun lahu mā fì 1-samāwāti wa-mā fì 1-arḍi wa-kafā billāhi wakīlan.

"O people of the Scriptures, do not transgress your religion, and do not speak to God except the truth. Indeed, the Messiah, Jesus the son of Mary, is the messenger of God and His Word which He has given to Mary, and from His Spirit. So believe in Allah and His apostles and do not say: "Three, stop. It's better for you. Indeed, Allah is the One and Only, the Glory of God from having children, all that is in heaven and on earth is His. " Enough is Allah for the Lord. In line with the above verse, the Bible never states that there are three Gods to be worshiped, and never gives birth to a child as His creation gives birth to a child, but God is the One in His allpowerful and Present
Being who has taken human form Jesus Christ.

\section{CONCLUSION}

The Trinity is the concept of the existence of God and the work of God in the form of three persons derived from what is reported in the Bible and consistent and in harmony with teaching throughout the Bible. The concept of trinity in Christianity does not at all explain the existence of three Gods, but one essence of God in the form of three persons. This explains how God took the form of a human being (Jesus) and was able to come into the world and be the savior of the world, and His Holy Spirit can live in everyone's life and lives. The greatness of God that is not limited by space and time is enables him to have nature just as the Bible reports his actions in the form of three persons.

The key to understanding the trinity is that one of the nature or character of God is omnipresent and that God is Spirit and unlimited by space and time. God that is not limited by space and time cannot be limited by human thought about His Oneness. So that His Essence here is One in the sense of its nature as it is nothing can compares and also no rivals. But not singular in the sense of His is measurable and limited form. If we call God one or only in the sense of being then we contradict it with His omnipresent.

As water and gas are things that categories as uncountable, so we cannot ask for as much water as one water or two gases. Moreover, the Spirit of God is infinite in space and time. $\mathrm{He}$ is everywhere. In Heaven, in the world even in the world of the dead He is present (Psalm 139).

God as Spirit that is not limited by space and time is enables him to took the form of a human being (Jesus) and was able to come into the world and be the savior of the world, and His Holy Spirit can live in everyone's life and lives.

The premises that God is almighty and omnipresent is harmony with His ability to be present without being limited by time and 
space. Likewise in the form of His presence. The essence of God is uncountable. It cannot be limited by the limitations of the human categorical mind. Therefore the concept of the Oneness of God, which refers to simple unity will cripple the concept of His omnipotence and omnipresence and it is contrary to the nature of God, the Almighty.

\section{REFERENCES}

[1]. Thiessen.,Henry C: Sistematic Theology

[2]. https://www.idpengertian.com/apayangdimaksud-dengan-definisi/ di kutip $15 / 9 / 2019$

[3]. Buswell, A Systematic Theology of the Christian Religion,

[4]. Hoeksema, Reformed Docmatics

[5]. Berkof, Systematic Theology,

[6]. Strong, Systematic Theology

[7]. Ryrie, Charles C; "Teologi Dasar 1", ANDI Offset, Yogyakarta.

[8]. Ryrie, Charles C; "Teologi Dasar 1", ANDI Offset, Yogyakarta, 2006.

[9]. Ludwig Wittgenstein, "Traktus LogicoPhilosophicus", London, Roudledge \& Kegan Paul, 1972

[10]. Karl Barth, Church Dogmatics, Vol II: The Doctrine of God, ed G.W Bromiley \& T.F. Torrance, New York: Scribner, 1957.

[11]. Nash, Ronald H,’Faith and Reason.

[12]. Thiessen.,Henry C: Teologi Sistematika, Gandum Mas, Malang, 2003.

[13]. Ryrie, Charles C; "Teologi Dasar 1", ANDI Offset, Yogyakarta, 2006.

[14]. Marantika, Chris: "Kristologi", Iman Press, Yogyakarta, 2008.
[15]. Marantika, Chris: "Yesus Kristus Allah, Manusia Sejati, Iman Press.

[16]. Power, Bernie; 'Understanding Jesus and Mohammad', Acorn Press, Moreland VIC, Autralia, 2016. 